\title{
PENGARUH LIKUIDITAS, SOLVABILITAS, DAN MANAJEMEN ASET TERHADAP KINERJA KEUANGAN PADA PERUSAHAAN GO PUBLIK YANG TERDAFTAR DALAM KOMPAS 100 DI INDONESIA
}

\author{
Wikan Budi Utami dan Sri Laksmi Pardanawati \\ STIE AAS Surakarta \\ Email :wikan.budiutami@yahoo.com
}

\begin{abstract}
ABSTRAK
Penelitian ini bertujuan untuk untuk mengetahui pengaruh pengaruh likwiditas, solvabilitas dan manajemen asset terhadap kinerja keuangan pada perusahaan go public yang terdaftar dalam kompas 100 Indonesia. Teknik penentuan sampel dalam penelitian ini adalah dengan menggunakan purposive sampling. Ada beberapa kriteria yang harus dipenuhi perusahaan yang terdaftar dalam Kompas 100 untuk dapat menjadi sampel dalam penelitian ini. Metode penelitian ini menggunakan analisa regresi berganda yang digunakan untuk mengetahui pengaruh variabel bebas terhadap variabel terikatnya secara bersamasama dan secara parsial. Dari hasil uji $F$ diketahui bahwa likwiditas, solvabilitas dan manajemen asset secara bersama-sama berpengaruh signifikan terhadap variabel kinerja keuangan pada perusahaan go publik yang terdaftar dalam Kompas 100 di Indonesia. Dari hasil uji $t$ diketahui bahwa likwiditas dan manajemen asset secara parsial berpengaruh signifikan terhadap variabel kinerja keuangan pada perusahaan go publik yang terdaftar dalam Kompas 100 di Indonesia, sedangkan solvabilitasi tidak berpengaruh signifikan terhadap kinerja keuangan pada perusahaan go publik yang terdaftar dalam Kompas 100 di Indonesia.
\end{abstract}

Kata kunci: likwiditas, solvabilitas, manajemen aset dan kinerja keuangan

\section{PENDAHULUAN}

Untuk menilai sejauh mana tingkat kekuatan ataupun kesehatan keuangan perusahaan, maka sebaiknya seorang manajer keuangan dapat menilai dan menganalisa kinerja keuangan dari perusahaannya.
Menurut Irhan Fahmi (2011:2) kinerja keuangan adalah suatu analisis yang dilakukan untuk melihat sejauh mana suatu perusahaan telah melaksanakan dengan menggunakan aturan-aturan pelaksanaan keuangan secara baik dan benar. Kinerja keuangan perusahaan selama beroperasi dapat terlihat melalui laporan keuangan 
yang berisi informasi mengenai data-data keuangan. Dengan menganalisa laporan keuangan akan membantu pihak-pihak yang berkepentingan dalam memilih dan mengevaluasi informasi. Analisa rasio keuangan adalah analisis laporan keuangan yang banyak digunakan karena penggunaannya yang relatif mudah.

Penilaian terhadap kinerja perusahaan sangatlah penting. Dengan mengadakan analisa rasio likwiditas, solvabilitas, analisa manajemen asset maka kinerja keuangan perusahaan bisa dinilai. Menurut Munawir (2000:31) tingkat likuiditas yaitu kemampuan perusahaan untuk memperoleh kewajiban keuangannya yang harus segera dipenuhi atau kemampuan perusahaan untuk memenuhi keuangannya pada saat ditagih, tingkat solvabilitas yaitu kemampuan perusahaan untuk memenuhi kewajiban keuangannya apabila perusahaan tersebut dilikuidasi baik kewajiban keuangan jangka pendek maupun jangka

Sebuah usaha dapat menganalisa laporan keuangan dengan membandingkan rasio- rasio keuangannya selama beberapa tahun untuk mengetahui bagaimana perkembangan kinerja perusahaan dari

\section{KAJIAN PUSTAKA}

\section{A. Landasan Teori}

1. Pengertian Kinerja Keuangan

Pengertian kinerja menurut Indra Bastian (2006:274) adalah gambaran pencapaian pelaksanaan/program/kebijaksanaan dalam mewujudkan sasaran, tujuan, misi dan visi suatu organisasi.Konsep panjang. Rasio aktivitas adalah rasio yang mengukur seberapa efektif perusahaan dalam memanfaatkan semua sumber daya yang ada padanya. Baik buruknya manajemen aset perusahaan bisa dilihat dari rasio aktivitasnya.

Rasio keuangan merupakan alat analisis perusahaan untuk menilai kinerja suatu perusahaan berdasarkan perbandingan data keuangan yang terdapat pada laporan pos keuangan (neraca, laporan/laba rugi, laporan arus kas). Rasio merupakan alat ukur yang digunakan perusahaan untuk mengenalisis laporan keuangan. Rasio menggambarkan suatu hubungan atau pertimbangan antara suatu jumlah tertentu dengan jumlah yang lain. Dengan menggunakan alat analisa berupa rasio keuangan dapat menjelaskan dan memberikan gambaran kepada penganalisa tentang baik atau buruknya keadaan atau posisi keuangan suatu perusahaan dari suatu periode ke periode berikutnya.

tahun ke tahun. Selain itu, dengan melakukan analisis terhadap rasio keuangan pihak manajemen dapat mengambil tindakan dan kebijakan yang tepat demi kelangsungan perusahaannya

kinerja keuangan menurut Indriyo Gitosudarmo dan Basri (2002:275) adalah rangkaian aktivitas keuangan pada suatu periode tertentu yang dilaporkan dalam laporan keuangan diantaranya laporan laba rugi dan neraca.

2. Tujuan analisis laporan keuangan

Tujuan analisis laporan keuangan yang paling utama adalah menganalisa 
kinerja perusahaan dalam upaya memberikan hasil yang optimal dalam kelangsungan usaha. Ada empat tujuan analisis laporan keuangan yaitu sebagai alat screening awal dalam memilih alternatif investasi atau merger. Kedua, sebagai alat forecasting mengenai kondisi kinerja keuangan di masa datang. Ketiga sebagai proses identifikasi awal terhadap masalah manajemen operasi atau masalah lainnya. Keempat sebagai alat evaluasi terhadap manajemen.

3. Analisis Rasio Keuangan

Dengan melakukan analisis rasio keuangan, manajemen dapat dinilai kinerja dari manajer keuangan apakah mereka dapat merencanakan dan mengimplementasikan ke dalam tindakan yang konsisten dengan tujuan mengoptimalkan keuntungan pemegang saham. Kemudian, analisa ini dapat juga digunakan oleh pihak lain di luar pemegang saham, misalnya bank untuk menilai apakah perusahaan cukup layak untuk diberikan tambahan dana atau kredit baru.

4. Jenis-Jenis Analisis Rasio Keuangan

Menurut Wild, Subramanyam, dan Halsey (2005) ada empat jenis analisis rasio yang bisa digunakan dalam penilaian kinerja keuangan perusahaan, meliputi: rasio likuiditas, rasio leverage, rasio aktivitas, dan rasio profitabilitas untuk memenuhi kebutuhan pihak-pihak yang berkepentingan sebelum pengambilan keputusan terhadap suatu perusahaan. Jenis-Jenis analisis rasio keuangan tersebut adalah:

a. Rasio Likuiditas Rasio likuiditas adalah rasio yang menunjukkan kemampuan perusahaan untuk memenuhi kewajiban finansial yang berjangka pendek tepat pada waktunya. Likuiditas perusahaan ditunjukkan oleh besar kecilnya aktiva lancar yaitu aktiva yang mudah diubah menjadi kas, meliputi kas, surat berharga, piutang dan persediaan. Rasio rasio yang digunakan dalam rasio likuiditas ada dua yaitu current ratio dan acid test ratio. Manfaat dari current ratio adalah mengukur kemampuan perusahaan memenuhi utang jangka pendeknya dengan menggunakan aktiva lancar. Sedangkan dengan perhitungan acid test ratio untuk mengukur seberapa besar kemampuan perusahaan dapat memenuhi kewajibannya tanpa terlalu tergantung pada persediannya.

b. Ratio Leverage

Ratio Leverage merupakan rasio yang menunjukkan kapasitas perusahaan untuk memenuhi kewajiban baik itu jangka pendek maupun jangka panjang. Jenis Jenis ratio leverage antara lain: Total Debt to Total Asset Ratio ( Rasio Hutang terhadap Total Aktiva ) dan Debt to Equity 
Ratio.

c. Activity Ratio/Rasio Aktivitas

Rasio aktivitas adalah rasio yang menunjukkan sejauh mana efisiensi perusahaan dalam menggunakan asset untuk memperoleh penjualan. Dari rasio aktivitas ini bisa dinilai manajemen asset perushaan.

d. Profitability Ratio

Rasio profitabilitas adalah rasio yang mengukur kemampuan perusahaan memperoleh laba dalam hubungannya dengan penjualan, total aktiva maupun modal sendiri. Manfaat rasio profitabilitas adalah untuk menunjukkan seberapa baik perusahaan telah beroperasi selama periode tahun berjalan, dan membantu investor dalam perhitungan laba serta mengetahui seberapa banyak yang dibayarkan sebagai dividen.

5. Pentingnya analisis rasio bagi perusahaan

Analisis rasio merupakan salah satu sumber informasi penting bagi para pemakai laporan keuangan dalam pengambilan keputusan ekonomi. Interpretasi terhadap laporan keuangan itu sangat diperlukan untuk memberikan gambaran tentang baik buruknya keadaan dan posisi keuangan suatu perusahaan agar dapat dipakai sebagai acuan bagi para pemilik, manajemen, kreditur dan pihak-pihak lain yang memerlukan.

\section{B. Penelitian Terdahulu}

Penelitian yang akan dilakukan didasarkan atas penelitian penelitian terdahulu, yaitu:

Pertama, penelitian yang dilakukan oleh Akhmad Syafrudin Noor (2011) yang meneliti tentang faktor faktor yang mempengaruhi kinerja keuangan perusahaan telekomunikasi yang go public di Bursa Efek Indonesia.

Kedua, penelitian yang dilakukan oleh IM. Sarjana, K.Budi Susrusa dan Dwi Putra Darmawan (2013) tentang analisis kinerja keuangan pada Koperasi Serba Usaha di Kabupaten Buleleng.

Ketiga, penelitian yang dilakukan oleh Endang Afriyeni (2008) tentang penilaian kinerja keuangan dengan menggunakan analisis rasio pada PT PQR tahun 2005- 2008.

Keempat penelitian yang dilakukan oleh Marsel Pongoh (2013) tentang analisis laporan keuangan untuk menilai kinerja keuangan PT Bumi Resources TBK.

\section{METODE PENELITIAN}

Penelitian ini bersifat deskriptif kuantitatif, yaitu menjelaskan hubungan antar variabel dengan menganalisa data numerik (angka) menggunakan metode statistik melalui pengujian hipotesa. Penelitian ini merupakan penelitian studi kasus pada perusahaan go public yang terdaftar dalam indek Kompas 100 tahun 2011-2013

A. Sumber Data, Populasi, Sampel, Metode Pengumpulan Data 
Data yang diperlukan dari penelitian ini terdiri dari Laporan Keuangan Tahunan (Annual Report) yang diterbitkan oleh perusahaan yang menjadi objek penelitian, yang dalam hal ini perusahaan yang tergabung dalam indeks Kompas 100.

Populasi dalam penelitian ini adalah perusahaan yang terdaftar dalam dalam kelompok indeks Kompas 100 pada tahun 2011-2013.

Teknik penentuan sampel dalam penelitian ini adalah dengan menggunakan purposive sampling. Kriteria perusahaan yang terdaftar dalam Kompas 100 untuk dapat menjadi sampel dalam penelitian ini adalah :

1. Perusahaan perusahaan manufaktur yang terdaftar dalam Kompas 100 yang pada tahun 2011-2013 kondisi keuangannya dalam keadaan likuid dan sovabel

2. Perusahaan tidak mengalami kerugian atau dengan kata lain dalam posisi laba selama periode penelitian.

Metode pengumpulan data dalam penelitian ini adalah metode dokumentasi dengan menggunakan data sekunder dari Bursa Efek Jakarta

\section{B. Variabel penelitian dan Definisi} Operasional Variabel

1. Variabel dependen dalam penelitian ini adalah kinerja keuangan perusahaan yang diukur dengan Return On Assets

$R$
$O$

A

$=$

Laba Bersih Setelah Pajak

Total assets

2. Variabel independen dalam penelitian ini adalah:

a. Rasio likwiditas yang diukur Current Ratio.Rasio likuiditas adalah rasio yang menunjukkan kemampuan perusahaan untuk memenuhi kewajiban finansial yang berjangka pendek tepat pada waktunya. (Wild, Subramanyam, dan Halsey, 2005) $C R=$ Current Assets

b. Rasio solvabilitas atau Leverage Ratio yang diukur dengan Debt To Total Assets Ratio

Solvabilitas $=\frac{\text { Total Debt }}{\text { Total Asets }}$

c. Manajemen asset yang diukur dengan Operating Assets

Turnover

Operating Assets Turnover

$=\frac{\text { Net Sales }}{\text { Total Operating Asset }}$

\section{Tehnik Analisis Data}

1. Regresi Berganda

Analisa regresi berganda digunakan untuk mengetahui pengaruh variabel bebas (likwiditas, solvabilitas dan manejemen aset) terhadap variabel terikatnya (kinerja 
keuangan) secara bersama-sama dan secara parsial. Dalam penelitian ini persamaan regresi bergandanya adalah:

$\mathrm{Y}=\mathrm{a}+\mathrm{b}_{1} \mathrm{X}_{1}+\mathrm{b}_{2} \mathrm{X}_{2}+\mathrm{b}_{3} \mathrm{X}_{3}+\mathrm{e}$

(Anto Dayan, 2000)

2. Uji-t

Uji $t$ ini digunakan untuk menguji pengaruh masing - masing variabel independen ( likwiditas, solvabilitas, manajemen aset) terhadap variabel dependen (kinerja keuangan).

3. Uji-F

Uji statistik $F$ bertujuan untuk menguji pengaruh semua variabel independen atau bebas (likwiditas, solvabilitas, manajemen aset) secara bersama-sama terhadap variabel dependen atau terikat (kinerja keuangan).

4. Koeficien determinasi $\left(\mathrm{R}^{2}\right)$

Uji ini dilakukan untuk mengetahui berapa besar pengaruh variabel independen terhadap variabel dependen.

\section{PEMBAHASAN}

\section{A. Analisis Regresi Berganda}

Uji statistik $\mathrm{t}$ dimaksudkan untuk mengetahui variance koefisien regresi secara parsial. Berdasarkan perhitungan regresi berganda antara likwiditas (CR), solvabilitas (DAR), manajemen asets OAT) dan kinerja keuangan (ROA) dengan menggunakan program SPSS 17, diperoleh hasil sebagai berikut:

Tabel 4.1

Tabel Regresi Linier Berganda (Uji Hipotesis)

\begin{tabular}{|l|l|l|l|}
\hline Variabel & Nilai $\beta$ & $\mathrm{t}$ & sig \\
\hline Konstanta & 0,787 & - & - \\
CR & 0,183 & 2,764 & 0,006 \\
DAR & -0.056 & $-0,827$ & 0,409 \\
OAT & 0,571 & 8,501 & 0,000 \\
\hline F hitung & 27.921 & & \\
Sig F & 0,000 & & \\
Adjusted R & 0,341 & & \\
\hline
\end{tabular}

Sumber: Data yang Diolah dengan SPSS 17

Dari hasil perhitungan tabel diatas dapat disajikan dalam bentuk persamaan regresi sebagai berikut:

$$
\begin{aligned}
& \mathrm{ROA}=0.787+0.183 \mathrm{CR}- \\
& 0.056 \mathrm{DAR}+0.571 \mathrm{OAT}+\mathrm{e}
\end{aligned}
$$

Hasil persamaan regresi berganda tersebut memberikan pengertian sebagai berikut:

1. Variabel likwiditas yang diukur dengan $\mathrm{CR}$ berpengaruh positif 
terhadap kinerja keuangan perusahaan (ROA) dengan nilai koefisien sebesar 0,183 . Hal ini menyatakan bahwa jika CR semakin tinggi, yang berarti perusahaan semakin likwid, maka kinerja keuangan perusahaan (ROA) semakin tinggi pula.

2. Variabel solvabilitas yang diukur dengan DAR berpengaruh negatif terhadap kinerja keuangan perusahaan (ROA) dengan nilai koefisien 0,056. Hal ini menyatakan bahwa semakin tinggi DAR (yang berarti solvabilitas semakin rendah) maka kinerja keuangan perusahaan (ROA) semakin rendah

3. Variabel manajemen asset yang diukur dengan OAT berpengaruh positif terhadap kinerja keuangan perusahaan (ROA) dengan nilai koefisien 0,571. Hal ini menyatakan bahwa semakin tinggi OAT yang berarti manajemen asetsnya semakin baik, maka kinerja keuangan perusahaan (ROA) semakin baik pula.

\section{B. Uji Signifikan Parameter Individual (Uji -t Statistik)}

1. Uji hipotesis likwiditas yang diukur dengan $\mathrm{CR}$ terhadap kinerja keuangan perusahaan yang diukur dengan ROA.

Dari hasil perhitungan yang diperoleh signifikasi $t$ untuk variabel likwiditas (CR) sebesar $0.006<\alpha(0,05)$. Hal ini berarti berarti likwiditas berpengaruh positif dan signifikan terhadap kinerja keuangan perusahaan .

2. Uji hipotesis solvabilitas yang diukur dengan DAR terhadap kinerja keuangan perusahaan (ROA).

Dari hasil perhitungan yang diperoleh signifikasi $\mathrm{t}$ untuk variabel solvabilitas yang diukur dengan DAR $\left(\mathrm{X}_{2}\right)$ sebesar 0.409 > a (0,05). Hal ini berarti solvabilitasi tidak berpengaruh signifikan terhadap kinerja keuangan perusahaan (ROA).

3. Uji hipotesis manajemen asset yang diukur dengan OAT terhadap kinerja keuangan perusahaan (ROA) .

Dari hasil perhitungan yang diperoleh signifikasi $t$ untuk variabel manajemen asset yang diukur dengan OAT sebesar $0.000<\alpha(0,05)$. Hal ini berarti manajemen asset (OAT) berpengaruh positif dan signifikan terhadap kinerja keuangan perusahaan (ROA) .

\section{Uji F}

Dari hasil perhitungan statistik menggunakan SPSS 17 yang tertera pada tabel diatas, diperoleh nilai $F$ hitung sebesar 27,921 dengan tingkat signifikansi 0,000 . Nilai signifikansi yang dihasilkan tersebut lebih kecil dari $\alpha=0,05$. Hal ini berarti bahwa variabel likwiditas (CR), solvabilitas (DAR), dan manajemen asset (OAT) secara simultan berpengaruh 
signifikan terhadap variabel kinerja keuangan perusahaan (ROA)

\section{Koefisien Determinasi $\left(\mathbf{R}^{\mathbf{2}}\right)$}

Dari hasil perhitungan dengan program SPSS dapat diketahui bahwa koefisien determinasi yang dapat dilihat dari Adjusted $R$ Square, diperoleh sebesar 0,341. Hal ini berarti 34,1\% kinerja keuangan perusahaan (ROA) dapat dijelaskan oleh variabel likwiditas (CR), solvabilitas (DAR) dan manajemen asset (OAT). Sedangkan sisanya $65,9 \%$ dijelaskan oleh variabelvariabel lainnya yang tidak diteliti dalam penelitian ini.

\section{E. Pembahasan}

Hasil penelitian ini menunjukkan variabel likwiditas (CR) berpengaruh positif dan signifikan terhadap variabel kinerja keuangan (ROA) perusahaan perusahaan go public yang terdaftar dalam Kompas 100 di Indonesia. Hasil tersebut bertentangan dengan penelitian Akhmad Syafrudin Noor (2011) dan IM.Sarjana, K,Budi Susrusa dan Dwi Putra Darmawan (2013).

Hasil penelitian Akhmad Syafrudin Noor (2011) yang menyatakan variabel current ratio tidak berpengaruh signifikan terhadap return on investment perusahaan telekomunikasi yang go public yang terdaftar di Bursa Efek Indonesia. Hasil penelitian IM.Sarjana, K,Budi Susrusa dan Dwi Putr Darmawan (2013) menyatakan secara parsial tak ada pengaruh variabel current ratio terhadap renabilitas ekonomi pada KSU di Buleleng.

Hasil penelitian ini menunjukkan variabel solvabilitas (DAR) berpengaruh negative dan tidak signifikan terhadat variabel kinerja keuangan (ROA) perusahaan go public yang terdaftar dalam Kompas 100 di Indonesia.

Hasil penelitian ini sejalan dengan penelitian Akhmad Syafrudin Noor (2011) yang menyatakan Debt Ratio secara parsial tidak berpengaruh terhadap Return On Investment perusahaan telekomunikasi yang go public yang terdaftar di Bursa Efek Indonesia.

Hasil penelitian ini bertentangan dengan hasil penelitin IM.Sarjana, K,Budi Susrusa dan Dwi Putr Darmawan (2013) yang menyatakan secara parsial terdapat pengaruh variabel debt to asset ratio terhadap rentabilitas ekonomi pada KSU di Kabupaten Buleleng.

Hasil penelitian ini menunjukkan variabel manajemen asset (OAT) berpengaruh signifikan terhadap kinerja keuangan (ROA) perusahaan perusahaan go public yang terdaftar dalam Kompas 100 di Indonesia. Hasil tersebut bertentangan dengan hasil penelitian Akhmad Syafrudin Noor (2011) yang menyatakan total assets turn over secara parsia tidak berpengaruh terhadap return on Investment perusahaan telekomunikasi yang go 
PENGARUH LIKUIDITAS, SOLVABILITAS, DAN MANAJEMEN ASET

TERHADAP KINERJA KEUANGAN PADA PERUSAHAAN GO PUBLIK

YANG TERDAFTAR DALAM KOMPAS 100 DI INDONESIA

public yang terdaftar di Bursa Efek Indonesia.

Berdasarkan hasil analisis data serta pembahasan yang dilakukan pada bagian sebelumnya, maka penelitian ini menghasikan beberapa kesimpulan sebagai berikut:

1. Likwiditas, solvabilitas dan manajemen aset secara simultan berpengaruh signifikan terhadap kinerja keuangan pada perusahaan go public yang terdaftar dalam Kompas 100 di Indonesia.

2. Solvabilitas berpengaruh negatif dan tidak signifikan terhadap kinerja keuangan pada perusahaan go public yang terdaftar dalam Kompas 100 di Indonesia.

3. Manajemen aset berpengaruh positif dan signifikan terhadap kinerja keuangan pada perusahaan go public yang terdaftar dalam Kompas 100 di Indonesia.

\section{B. Saran}

1. Para investor kebanyakan menilai kinerja keuangan dari nilai likwiditas perusahaan. Meskipun demikian hendaknya perusahaan-perusahaan tak hanya menfokuskan perhatian pada likuiditan perusahaan (Current Ratio) saja. Terlalu besarnya nilai likuiditas perusahaan berdampak negatif terhadap profitabilitas

4. adanya peningkatan profit yang diperoleh perusaaahan adalah kemampuan investasi perusahaan

\section{KESIMPULAN}

\section{A. Kesimpulan}

perusahaan yang disebabkan banyaknya dana yang menganggur. Demikian pula terlalu besarnya solvabilitas perusahaan juga beresiko terhadap kinerja keuangan/profitabilitas perusahaan.

2. Perusahaan-perusahaan hendaknya senantiasa memperhatikan manajemen asetnya. Manajemen asset yang tercermin dari tingkat perputan aktiva (Total Assets Turn Over) akan berbengaruh signifikan terhadap kinerja keuangan (ROA) Perusahaan tersebut. Perusahaan hendaknya mengelola aktiva perusahaan secara efektif dan efisien sehingga pendapatan perusahaan meningkat. Melakukan optimalisasi terhadap manajemen asset yang tercermin Total Assets Turn Over akan meningkatkan kinerja keuangan perusahaan (Return On Assets)

3. Return On Assets perusahaan dapat ditingkatkan dengan melakukan efisiensi biaya-biaya operasional perusahaan sehingga profit yang diperoleh meningkat. Dampak selanjutnya dengan

untuk kegiatan ekspansi usaha meningkat pula 


\section{DAFTAR PUSTAKA}

Akhmad Syafrudin Noor. Faktor Faktor Yang Mempengaruhi Kinerja Keuangan Perusahaan Telekomunikasi Yang Go Publik Di Bursa Efek Indonesia. Jurnal Akuntansi dan Manajemen, April 2011 Volume 12 No. 1 Hal.13-24

Anto Dayan. 2000. Pengantar Metode Statistik. Jilid 2 Jakarta : PT Pustaka LP3ES

Bastian, Indra. 2006. Pengukuran Kinerja Sektor Publik. Yogyakarta : BPFE

Endang Afriyeni. Penilaian Kinerja Keuangan dengan Menggunakan Analisis Rasio. Jurnal Ekonomi dan Bisnis. Oktober 2008, Vol. 3, No. 2, Hal. 109 - 118.

Fahmi, Irham. 2011. Analisis Laporan Keuangan. Lampulo: ALFABETA.

IM. Sarjana,K Budi Susrusa dan Dwi Putra. Analisa Kinerja Keuangan Pada Koperasi SerbaUsaha Di Kabupaten Buleleng. Jurnal Manajemen Agribisnis Vol. 1, No. 2, Oktober 2013, Hal 16-22

Indriyo Gitosudarmo dan Basri. 2002.

Manajemen Keuangan. BPFE:

Yogyakarta

John J.Wild., K,R. Subramanyam., dan Robert F. Halsey. (2007).
Financial Statement analysis.

$9^{\text {th }}$ edition. McGraw-Hill.

Marsel Pongoh. Analisis Laporan Keuangan Untuk Menilai Kinerja Keungan PT Bumi Resources TBK. Jurnal Emba. Vol.1 No. 3 September 2013, Hal 669-679

S.Munawi.2000. Analisa Laporan Keuangan.Yogyakarta: Liberty 